\title{
Stable isotopes in adipose tissue fatty acids as indicators of diet in arctic foxes (Alopex lagopus) \\ BY CAROLINE M. POND ${ }^{1}$ AND IAIN GILMOUR ${ }^{2}$ \\ ${ }^{1}$ Department of Biology and ${ }^{2}$ Planetary Sciences Research Institute, The Open University, Milton Keynes $M K 76 A A$
}

The key to successful nutrition of captive animals is understanding the species' natural diet. Simply observing which foods the animals accept and what can sustain non-breeding adults are often not sufficient to establish the dietary requirements for a permanent breeding population. Diet is particularly important for reproduction, and may be a cryptic cause of infertility or unsuccessful breeding. The lactation habit enables mammals to nourish their offspring from body stores of lipid, protein and minerals, thereby freeing them from dependence on local food sources and enabling them to breed in a wider range of habitats than is usually possible for birds or reptiles. But in the long term, diet is just as important; the reserves of the nutrients necessary for reproduction have to be built up for some time.

Obtaining a comprehensive picture of wild animals' diets is difficult. Direct observation of foraging behaviour and food choice for short periods (Nielsen, 1991; Stickney, 1991) or the examination of crop or stomach contents (Unander et al. 1985; Frafjord, 1993) are time-consuming or destructive methods that at best provide only a limited picture of the habits of a small population at a certain season. Culling is wasteful, particularly in the case of carnivores, because the stomach is empty, or its contents are digested beyond recognition, in a large proportion of the specimens (Prestrud, 1992a; Pond et al. 1994, 1995a). The analysis of faeces depends on incomplete digestion of tissues such as hair, feathers, seeds or skeletal tissues (Hersteinsson \& Macdonald, 1996), and works well only for certain species.

These methods at best only quantify nutrient intake; they reveal nothing of which components of the food are utilized or excreted, and which are retained in storage tissues for use during breeding, hibernation, migration or other periods when food intake cannot match nutrient demand. They may also fail to detect foods that are eaten in small quantities or only occasionally, that nonetheless provide essential nutrients such as vitamins, minerals and essential fatty acids. Many wild animals apparently have large reserves of some of these minor but important nutrients. Symptoms of diseases caused by nutritional deficiencies are often vague and difficult to recognize, and in the case of captive animals, may only become apparent after months or years on an artificial diet.

Vertebrates, especially large omnivores and predators, are dietary generalists that can prosper on a wide range of foods. Brief snapshots of the foods eaten by certain individuals or a small population often fail to reveal the complete picture. Morphologically identical populations may differ enormously in food choice and foraging strategies, but may still achieve similar nutritional status. Isotopic methods of food-web analysis offer several advantages over these conventional methods; the stable-isotope composition reflects the time-integrated average of the assimilated diet, thereby enabling the nutritional dependence of an animal on a particular food source to be assessed. Ecologists want to know the origin of particular molecules in order to trace nutritional relationships between species, and pathways of nutrients through ecosystems. Nutritionists are concerned with how much of what kinds of materials constitute an ideal diet. 


\section{FATTY ACIDS AS INDICATORS OF DIETARY HISTORY}

Fatty acids are particularly suitable as indicators of long-term dietary habits because, except in ruminants, the processes of digestion and absorption do not alter the hydrocarbon chains. The fatty acids pass intact from the food to storage tissue, where they remain (although subject to continuous turnover) until they are incorporated into more complex lipids or are oxidized. In non-ruminants, therefore, the relative abundance of different kinds of triacylglycerol-fatty acids corresponds approximately to that of their average diet over a period of months.

The ecological origin of triacylglycerol-fatty acids can be determined from their chemical structure (Reidinger et al. 1985; Rouvinen \& Kiiskinen, 1989; Tjønneland et al. 1993; Pond et al. 1995a). Most vertebrates can synthesize saturated long-chain fatty acids and the common monounsaturates from carbohydrate or short-chain fatty acid precursors, but polyunsaturates are derived only from the diet. With a few exceptions, most of the polyunsaturated fatty acids synthesized by terrestrial plants are of the $n-6$ series, while those produced by aquatic algae are mostly of the $n-3$ series. Most plant fatty acids include up to eighteen carbon atoms and have two or three double bonds, but marine invertebrates and fish can elongate and desaturate them further to produce long-chain, highly unsaturated 'fish oils'. Birds and mammals that feed partly or entirely in the marine ecosystem take in more of these fatty acids than those that eat from terrestrial food chains.

If the fatty acids pass unaltered from food to adipose tissue triacylglycerols, and are stored in the proportions in which they are ingested, the relative abundance of fatty acids is a crude indicator of the diet. Ruminants, and to a lesser extent other herbivores that harbour gut symbionts, are the chief source of major modifications to fatty acids made by the primary producers. Micro-organisms in the rumen or colon desaturate double bonds, convert cis bonds to the trans configuration and otherwise modify many of the fatty acids in the food. The symbionts also synthesize short-chain fatty acids from the simple sugars that are liberated from the breakdown of cellulose and starches. Thus, ruminant adipose tissue and milk lipids contain a much higher proportion of saturated and trans-unsaturated fatty acids, and fewer polyunsaturates, than were in their diet.

Carnivores are particularly suitable subjects in which to trace the ecological origins of fatty acids because, since their diet usually contains plenty of animal fats, their capacity for de novo lipid synthesis and for chemical modification of fatty acids is much lower than that in herbivores. Rats and probably most other herbivores can synthesize saturated and monoenoic fatty acids from carbohydrate precursors, thus, on a low-fat diet, most of their storage lipids are of endogenous origin, while those of carnivores and omnivores such as man are derived directly from the diet. The rat liver also desaturates and/or elongates certain polyunsaturated fatty acids, thereby raising their abundance in the tissues above that of the diet (Gurr \& Harwood, 1991). But the capacity to elongate and desaturate fatty acids is weak in vertebrates that eat other vertebrates; the activity of $\Delta 6$ desaturase is very low in cats, and in microsomes isolated from dogs' livers (Brenner, 1989). Lipid metabolism has not been studied in Alopex, but it is unlikely to be capable of more extensive transformations than that of dogs.

\section{STABLE ISOTOPES IN THE IDENTIFICATION OF NATURAL DIETS}

Tracing the ecological origins of biological materials such as fatty acids can be further refined by studying their isotopic composition. Stable isotopes last for ever, and they lack the safety hazards of radioactive isotopes. Their use in the study of human metabolism has been reviewed recently in the Proceedings of the Nutrition Society (Beylot, 1994) and will 
not be further discussed. Analysis of the natural abundance of stable isotopes is widely used to trace the flow of organic $\mathrm{C}$ and $\mathrm{N}$ in both modern and ancient food webs (DeNiro \& Epstein, 1978; Chisholm et al. 1982; Schoeninger et al. 1983; Fry \& Sherr, 1984; Wada et al. 1991; Ostrom \& Fry, 1993) and more recently to determine the diets of individual populations and subpopulations (Angerbjörn et al. 1994). The procedure is based on the observation that the natural abundances of $\mathrm{C}$ and $\mathrm{N}$ isotopes in a consumer organism are similar to, or vary predictably from, those of its food.

$\mathrm{C}$ is the easiest element with which to trace the origin of most kinds of organic matter because it is very abundant in almost all biological materials, and it burns easily (essential for the final stage of mass spectrometry). The isotopic ratios for the stable isotopes of $\mathrm{C}$ are expressed in the usual $\delta$ notation relative to the Peedee belemnite (PDB) standard as follows:

$$
\delta^{13} \mathrm{C}_{\mathrm{PDB}}(\%)=\left(\frac{{ }^{13} \mathrm{C} \text { sample }}{\frac{{ }^{12} \mathrm{C}}{{ }^{12} \mathrm{C}} \text { standard }}-1\right) \times 1000 .
$$

The proportion of ${ }^{13} \mathrm{C}$ in the standard, ${ }^{13} \mathrm{C} /{ }^{12} \mathrm{C}=0.01124$ (i.e. $99.11 \%$ of atoms are ${ }^{12} \mathrm{C}$ ), is about typical for inorganic materials, including the $\mathrm{HCO}_{3}{ }^{-}$from which the $\mathrm{CaCO}_{3}$ in the original shell of the fossil belemnite was formed. Almost all fossil and modern organic matter contains a lower proportion of ${ }^{13} \mathrm{C}$, thus, their $\delta^{13} \mathrm{C}$ values are always negative; a less-negative value means that the sample is richer in ${ }^{13} \mathrm{C}$, or 'heavier'. Isotopic fractionation during the uptake of inorganic $\mathrm{C}$ into plant cells and its fixation into organic material produces a depletion of ${ }^{13} \mathrm{C}$ in biological materials relative to inorganic $\mathrm{C}$ (O'Leary, 1981). Differences in the primary sources of inorganic $\mathrm{C}$, the physical mechanisms of its uptake and the metabolism of the organisms themselves all contribute to further discrimination against ${ }^{13} \mathrm{C}$. They determine the molecules' final 'isotopic signature', which can indicate the biological source of the material (O'Leary, 1981).

Aquatic algae take up $\mathrm{C}$ as dissolved $\mathrm{HCO}_{3}{ }^{-}$, but terrestrial plants take up atmospheric $\mathrm{CO}_{2}$. Equilibrium fractionation in aquatic systems between $\mathrm{CO}_{2}$ and dissolved $\mathrm{HCO}_{3}{ }^{-}$ causes a difference between the $\delta^{13} \mathrm{C}$ values of atmospheric $\mathrm{CO}_{2}(-8 \%)$ and marine bicarbonate $(0 \%$ ). The heavier isotopes also diffuse through plant cell membranes less readily, and enzymes of the initial stages of photosynthesis discriminate against heavier atoms, so photoautotrophs are depleted in ${ }^{13} \mathrm{C}$ by approximately $10-20 \%$ with respect to their inorganic $\mathrm{C}$ source. At similar levels in the food chains, the heavier isotope $\left({ }^{13} \mathrm{C}\right)$ is about 5-7\% more abundant in the tissues of animals that eat marine foods than those feeding from the terrestrial food chain (Chisholm et al. 1982; Ostrom \& Fry, 1993).

The relative abundance of $C_{4}$ and $C_{3}$ plants in herbivores' diets also affects the isotope composition of the $\mathrm{C}$ atoms in their tissues, and, hence, those of consumers higher up the food chain (Schell \& Ziemann, 1989). These two alternative pathways of fixation of atmospheric $\mathrm{CO}_{2}$ are so called because the initial product of photosynthesis is a threecarbon molecule in $\mathrm{C}_{3}$ plants, and a four-carbon molecule in $\mathrm{C}_{4}$ plants. The key enzyme that fixes $\mathrm{CO}_{2}$ in $\mathrm{C}_{3}$ plants discriminates more strongly against ${ }^{13} \mathrm{CO}_{2}$ than that of $\mathrm{C}_{4}$ plants, thereby creating differences of up to $15 \%$ in the isotope composition of the primary products of the $C_{3}$ and $C_{4}$ pathways of photosynthesis (Smith \& Epstein, 1971). This difference in the $\mathrm{C}$-isotope composition of the entire plant, including its lipids, persists as the organic materials pass up the food chain.

The more diverse and usually more abundant $\mathrm{C}_{3}$ plants have $\delta^{13} \mathrm{C}$ values averaging $-26.5 \%$, while those of $\mathrm{C}_{4}$ plants, that comprise less than $0.5 \%$ of all known species of 
flowering plants, but include some widely-cultivated crops such as maize and sugar-cane (Saccharum officinarum), are about $-12.5 \%$. Further discrimination against the heavier isotope by herbivores and their predators may reduce the $\delta^{13} \mathrm{C}$ value for fatty acids that originated in terrestrial $\mathrm{C}_{3}$ plants to about $-33 \%$. After correction for the effects of the consumers' metabolism and biosynthesis, the C-isotope signatures of their tissues can be used to estimate the proportions of foods of marine or terrestrial origin in their diets (Chisholm et al. 1982).

Further discrimination between ${ }^{12} \mathrm{C}$ and ${ }^{13} \mathrm{C}$ takes place in the plant tissues and in those of the consumers as the material progresses through the food chain. Various studies have documented small shifts of +1 to $+2 \%$ in $\delta^{13} \mathrm{C}$ between consumers and their food sources (DeNiro \& Epstein, 1978; Fry \& Sherr, 1984). The precise magnitude of this shift depends on the extent to which the heavy isotope is incorporated or eliminated during metabolic processes. Respiration selectively excretes the lighter ${ }^{12} \mathrm{C}$ atoms as $\mathrm{CO}_{2}$; thus, the ${ }^{13} \mathrm{C}$ isotopes accumulate to a small extent in the tissues, which are then consumed by animals higher up the food chain.

Chemical modifications in vivo that involve breaking or making $\mathrm{C}$ bonds, including elongation and desaturation of fatty acids, favour ${ }^{12} \mathrm{C}$ atoms over the ${ }^{13} \mathrm{C}$ isotope because of the lower energy required to make or break a ${ }^{12} \mathrm{C}-{ }^{12} \mathrm{C}$ bond compared with a ${ }^{13} \mathrm{C}-{ }^{12} \mathrm{C}$ bond, a process referred to as the kinetic isotope effect. This bias means that the products of such in vivo modifications are slightly lighter than the precursors from which they were synthesized in the same organism and than unaltered fatty acids that were synthesized further down the food chain. Consequently, differences in the relative proportions of ${ }^{13} \mathrm{C}$ and ${ }^{12} \mathrm{C}$ in any organic materials, including lipids, made by marine or terrestrial organisms, are maintained through successive trophic levels in both marine and terrestrial food webs (Chisholm et al. 1982).

The biosynthesis and later modifications of lipids discriminate particularly strongly against the heavier isotope; thus, in both plants and animals, the lipids are more depleted in ${ }^{13} \mathrm{C}$ than the average of the tissues as a whole (DeNiro \& Epstein, 1977) and than carbohydrates and proteins (Tieszen et al. 1983). Thus, the average C-isotope composition of lipids extracted from the adipose tissue of polar bears (Ursus maritimus) and ringed seals (Phoca hispida) was found to be 9-10\% lighter than those of bone collagen from the same specimens (Ramsay \& Hobson, 1991).

In most tissues, turnover of collagen is very slow, and that of bone has the advantage of surviving unaltered for years post mortem, so it can be extracted from fragments of dried skeletons. Studies of the proportions of $\mathrm{C}$ and/or $\mathrm{N}$ isotopes in bone collagen (Schoeninger \& DeNiro, 1984; Tuross et al. 1988; Ostrom et al. 1990; Angerbjörn et al. 1994) have yielded information on the lifetime average diet of animals. Similar techniques have provided information on the relative sources of animal and vegetable protein (Ambrose \& DeNiro, 1986), changes in trophic level of food sources (Thompson et al. 1995), or the relative contributions of marine and terrestrial foods (Chisholm et al. 1982; Schoeninger et al. 1983; Ambrose \& DeNiro, 1986; Cormie \& Schwarcz, 1994; Tykot et al. 1996). However, with isotope analysis of whole-tissue or whole-organism samples an estimate of the trophic fractionation has to be taken into account when calculating the contribution of a particular food source to the diets (Harrigan et al. 1989).

Quantification of stable isotopes has recently been extended to examine the isotope composition of individual compounds of dietary importance. The ability to measure the isotope compositions of individual compounds in a complex mixture, termed compoundspecific isotope analysis (CSIA), has been a long-held goal of stable-isotope mass spectrometry (Matthews \& Hayes, 1978; Engel \& Macko, 1984; Gilmour et al. 1984). But 
combining gas chromatography with isotope-ratio mass spectrometry (GC-IRMS; Hayes et al. 1990) has enabled the isotopic compositions of individual compounds to be determined to high levels of precision in complex mixtures and seen the application of CSIA to an increasing range of geochemical and biological problems (Guo et al. 1993; Gilmour \& Pillinger, 1994; Schoell \& Hayes, 1994).

Des Marais et al. (1980) were able to use the C-isotope composition of individual $n$ alkanes isolated from bat guano to distinguish the primary food sources of insectivorous bats from Carlsbad, New Mexico. They found that the $\delta^{13} \mathrm{C}$ values of the individual $n$ alkanes preserved the $\mathrm{C}$-isotope composition of $\mathrm{C}_{3}$ and $\mathrm{C}_{4}$ plants eaten by the insects that were the bats' primary food.

The improved sensitivity of the new GC-IRMS has also led to new applications using tracers enriched with stable isotopes. For example, Metges et al. (1996) used compoundspecific isotope analysis to measure the $\delta^{15} \mathrm{~N}$ values of individual $\mathrm{N}$-acetyl and $\mathrm{N}$-pivaloyl amino acids as part of a pilot study on amino acid synthesis in pigs. Similarly, Guo et al. (1993) applied ${ }^{13} \mathrm{C}$-labelled cholesterol in stable-isotope studies of human cholesterol metabolism and Binnert et al. (1995) studied fatty acid metabolism in human subjects using ${ }^{13} \mathrm{C}$-labelled palmitate, either taken orally or infused.

The isotope composition of individual fatty acids is controlled by the nature and availability of $\mathrm{C}$ sources and biosynthetic fractionations associated with the metabolism of the animal. A complicating requirement for the measurement of the $\mathrm{C}$-isotope composition of individual fatty acids is that they need to be derivatized to their more volatile methyl esters for GC, which introduces an additional step in their isotope analysis as an extra C atom is added to the molecule.

In the case of amino acids and carbohydrates, derivatization is known to be accompanied by isotope fractionations requiring time-consuming individual corrections for each compound studied (Silfer et al. 1991; Moers et al. 1993). But several studies have concluded that there is no evidence for isotope fractionation at the methyl-C during methylation of fatty acids with $\mathrm{BF}_{3}$-methanol (Abrajano et al. 1994; Gilmour et al. 1995; Johnston et al. 1995). It is possible, therefore, to evaluate intermolecular C-isotope variations in natural fatty acids by determining the $\mathrm{C}$-isotope composition of the corresponding methyl esters after derivatization, i.e. for the derivatization reaction:

$$
\mathrm{R}-\mathrm{COOH}+\mathrm{CH}_{3} \mathrm{OH} \stackrel{\mathrm{BF}_{3}}{\longrightarrow} \mathrm{R}-\mathrm{COOCH}_{3}+\mathrm{H}_{2} \mathrm{O} .
$$

The stoichiometric mass balance for fatty acid methyl esters (FAME) can be written as:

$$
\delta^{13} \mathrm{C}_{\mathrm{FAME}}=\mathrm{X}\left(\delta^{13} \mathrm{C}_{\mathrm{FA}}\right)+(1-\mathrm{X})\left(\delta^{13} \mathrm{C}_{\mathrm{Me}}\right),
$$

where $\delta^{13} \mathrm{C}_{\mathrm{FAME}}, \delta^{13} \mathrm{C}_{\mathrm{FA}}$, and $\delta^{13} \mathrm{C}_{\mathrm{Me}}$ are the $\mathrm{C}$ isotopic compositions of the methyl ester, the underivatized fatty acid, and the methanol respectively, and $\mathrm{X}$ and $1-\mathrm{X}$ are the mole fractions of $\mathrm{C}$ from each source. Thus, a simple mass balance calculation can be used to determine the correct isotope composition for each fatty acid.

There are only limited data available in the literature on the isotope composition of individual fatty acids because, until recently, most analyses of food webs involving stable isotopes have used protein or protein-rich tissues (McConnaughey \& McRoy, 1979; Ramsay \& Hobson, 1991; Angerbjörn et al. 1994). Several recent studies have used CSIA of fatty acids to examine $C$ flow in marine ecosystems. Abrajano et al. (1994) found that two species of mussels from coastal Newfoundland have fatty acid $\delta^{13} \mathrm{C}$ values of -34.4 to $-24.9 \%$, whereas those from the Gulf of Mexico were in the range -56.9 to $-49.0 \%$. This difference was attributed to the difference in the ultimate source 
of $\mathrm{C}$ in the two environments $\left(\mathrm{CO}_{2}\right.$ in coastal Newfoundland and $\mathrm{CH}_{4}$ in the Gulf of Mexico).

Johnston et al. (1995) measured the C-isotope composition of individual fatty acids to examine how the transfer of photosynthates from zooxanthellae symbiotic with tridacnid clams contributed to the clams' success on the Australian Great Barrier Reef. They found that some fatty acids in host tissues had $\delta^{13} \mathrm{C}$ values similar to those of their respective algae, interpreted as direct translocation of these acids from algae to host, while others were ${ }^{13} \mathrm{C}$-depleted when compared with the corresponding acids in the algae, which implied multiple sources for these acids. Murphy \& Abrajano (1994) examined the Cisotope compositions of free fatty acids of two species of mussels from two estuarine environments in Newfoundland, Canada. They observed a $7 \%$ range in the $\delta^{13} \mathrm{C}$ values of individual fatty acids within single specimens and found that, in general, saturated fatty acids were isotopically heavier than the corresponding mono- and polyunsaturates, consistent with a kinetic isotope effect associated with desaturation reactions.

These studies have demonstrated the potential for CSIA to examine the sources of lipids in food webs. In animals in which the triacylglycerol-fatty acids pass unchanged (apart from several rounds of hydrolysis and re-esterification, which do not affect the $\mathrm{C}$ atoms of the fatty acids) from food to body tissues, the proportions of ${ }^{13} \mathrm{C}$ and ${ }^{12} \mathrm{C}$ isotopes in their $\mathrm{C}$ skeletons reveal the major sources of dietary lipids over the previous weeks or months.

\section{ARCTIC FOXES (ALOPEX LAGOPUS) ON SVALBARD}

Arctic foxes are widespread in the Arctic and in high mountains at lower latitudes; in fact, almost anywhere in the northern hemisphere where the climate is too cold for the larger red fox to survive. They are active all winter, and can travel long distances both over land and across frozen seas, so they have colonized all but the smallest islands of the Arctic Ocean and Hudson Bay.

Like most canids, arctic foxes are opportunistic feeders, and can prosper on a wide variety of foods. On mainland Europe, Asia and North America and large islands such as Greenland, they eat small rodents and lagomorphs (Garrott et al. 1983; Smits et al. 1989), sometimes being so heavily dependent on lemmings as prey that their numbers fluctuate from year to year according to the abundance of lemmings. But when these prey become rare, and on small islands with impoverished fauna, foxes eat substantial quantities of birds, such as gulls, auks, ducks and ptarmigan, as well as fish, large invertebrates and carrion (Quinlan \& Lehnhausen, 1982; Fay \& Stephenson, 1989; Nielsen, 1991; Stickney, 1991). They apparently thrive on diets derived almost entirely from the marine food chain and have decimated some breeding colonies of sea-birds on islands to which they have recently been introduced.

Their diverse diet makes arctic foxes a particularly suitable species in which to assess the contributions of the marine and terrestrial food chains to the diet from measurements of the chemical and isotope composition of storage lipids. The Svalbard population has the further advantage that their diet is atypical because only a few kinds of food are available on the islands. There are no lemmings, or any other native rodents, nor hares, no freshwater fish (the species failed to colonize this isolated archipelago after the end of the last glaciation), and only two native terrestrial mammals, the Svalbard reindeer (Rangifer tarandus platyrhynchus) and the arctic fox, and one resident bird, the Svalbard ptarmigan (Lagopus mutus hyperboreus), that is nowhere very common.

Being only about the size of a domestic cat, arctic foxes are too small to kill healthy adult reindeer, but they scavenge the carcasses of reindeer that have died from other causes 
(often starvation) and occasionally kill neonates or very sick specimens (Prestrud, 1992a; Frafjord, 1993). From May to August, they take the eggs and young of geese, eider ducks, kittiwake gulls (Rissa tridactylus), fulmars (Fulmarus glacialis), puffins and auks (Frafjord, 1993) that migrate to Svalbard for a few months in summer to breed. Apart from the geese, these birds feed from the marine food chain, taking fish and invertebrates from the rich coastal waters. When the fjords are frozen over and the migratory birds have gone, coastal foxes living in areas where reindeer are scarce may follow polar bears onto the sea-ice, and scavenge the remains of the seals that they kill (Stirling, 1988).

Svalbard has no trees or other flowering plants large enough to produce fruits or seeds that could form a digestible meal for foxes. $\mathrm{C}_{4}$ plants do best in hot, arid climates where the leaves are exposed to strong sunlight for a large part of the day. The continuous cold and low light intensity in the high Arctic preclude their presence (Tieszen \& Boutton, 1988): even Spartina, a $\mathrm{C}_{4}$ genus that is common in temperate-zone salt marshes, has not been recorded on Svalbard (Rönning, 1979). Arctic foxes in the more temperate climate of Iceland eat significant quantities of littoral invertebrates and algae (Hersteinsson \& Macdonald, 1996), but at $78^{\circ} 50^{\prime} \mathrm{N}$, the sea is frozen for much of the year, and the beaches support few organisms. Thus, the proportion of vertebrates in the diet of Svalbard arctic foxes must be greater than that of almost all temperate zone and tropical canids, probably as high as that of any felid.

Many carnivores, especially boreal species, become obese when food is plentiful, but arctic foxes on Svalbard become particularly fat, reaching as much as $330 \mathrm{~g}$ dissectible adipose tissue/kg body weight (Pond et al. 1995a). Fatness varies enormously between specimens collected from the same area, but average values do not differ consistently during the year, in spite of the very large seasonal changes in the foods available and the environmental temperature at such high latitudes (Prestrud \& Nilssen, 1992). Such data reveal no evidence for seasonal fasting or migration, and suggest that obesity is an adaptation to the irregularity and unpredictability in food supply at high latitudes. Alopex seems to have taken to extremes the canid traits of adaptable dietary requirements and an ability to gorge themselves if and when food becomes available.

Observations on free-ranging American badger (Taxidea taxus) and coyote (Canis latrans; Harlow \& Varnell, 1980), mongooses (Reidinger et al. 1985), mink (Mustela vison) and arctic fox (Rouvinen \& Kiiskinen, 1989) that are wild-caught but kept in captivity for short periods, and on zoo-bred polar bears (Colby et al. 1993) indicate that diet determines the fatty acid composition of adipose tissue triacylglycerols in Carnivora at least as well as in any other single-stomached mammals. Small carnivores seem to retain fatty acids derived from fish oils particularly efficiently (Rouvinen et al. 1993).

The animal fats available to Svalbard arctic foxes are of contrasting composition. Reindeer are ruminants, hence a high proportion of their triacylglycerol-fatty acids are saturated. Their average unsaturated index (\% monoenoic $+2(\%$ dienoic $)+3$ (\% trienoic)... etc.) is approximately 40 (Pond et al. 1993), while that of polar bear adipose tissue is about 153 (Pond et al. 1992). Unfortunately, there are no data on the fatty acids of ptarmigan, a major terrestrial source of food for foxes on Svalbard (Prestrud, 1992a). Analysis of the birds' gut contents (Unander et al. 1985) shows that ptarmigan eat buds, leaves and fruit of herbaceous plants, particularly Salix polaris, Polygonum and Saxifraga spp. As well as contrasts in the relative abundance of fatty acids with different degrees of saturation, the polyunsaturates from the marine food chain are mainly $n-3$, while those derived from terrestrial plants are mostly $n-6$. These contrasts in the fatty acids from the two ecosystems should allow identification of the origins of those in arctic-fox lipids on the basis of their chemical composition. 
Such conclusions can be confirmed and refined by measuring the relative abundance of isotopes. Because of the unique habits of this species, the differences in isotope composition were expected to be large enough to be easily resolved by our equipment and analyses. The mean $\delta^{13} \mathrm{C}$ value for adipose-tissue lipids measured in polar bears from the Northwest Territories of Canada that feed exclusively in the marine food chain was $-24.7 \%$ (Ramsay \& Hobson, 1991). The mean $\delta^{13} \mathrm{C}$ values of tissues of North American caribou (reindeer: Rangifer tarandus caribou) known to have been eating $\mathrm{C}_{3}$ plants are -26.8 to $-28.7 \%$ (Schell \& Ziemann, 1989), but are probably lower still for lipids alone. Lipids derived from terrestrial plants via reindeer or ptarmigan should thus be distinguishable by the relative abundance of their $\mathrm{C}$ isotopes from those that originated from the sea and reached foxes via sea-birds, fish or carrion.

\section{CHEMICAL AND ISOTOPIC ANALYSIS OF TRIACYLGLYCEROL-FATTY ACIDS}

The carcasses of foxes that had been collected for their valuable pelts were stored frozen for several months until dissected, and samples of adipose tissue brought back for analysis. Fig. 1(a) shows the strong correlations between the $\delta^{13} \mathrm{C}$ values and their relative abundance in the triacylglycerols extracted from adipose tissue for the two most-abundant saturated fatty acids, palmitic acid $\left(\mathrm{C}_{16: 0}\right)$ and stearic acid $\left(\mathrm{C}_{18: 0}\right)$, and the monoenoic, palmitoleic acid $\left(\mathrm{C}_{16: 1 n-7}\right.$; Pond et al. 1995b). No such association was found for the most abundant unsaturated fatty acids, oleic acid (18:1n-9) and gondoic (20:1n-9; Fig. 1(b)).

These associations provide evidence for a single dominant dietary source of certain fatty acids. Foxes whose diet had included more stearic and palmitic acids had triacylglycerol-fatty acids with an isotope signature closer to that of $\mathrm{C}_{3}$ terrestrial plants. A large proportion of the triacylglycerol-fatty acids in reindeer adipose tissue are saturated, with stearic and palmitic the most abundant (Pond et al. 1993). The inverse relationship found for palmitoleic acid indicates that the few foxes in which it was present in substantial quantities obtained it mainly from the marine food chain. The other monoenoics (Fig. 1(b)) appear to be derived from either source in about equal proportions, so that their average isotope composition, although quite variable between individuals, is not associated with their abundance in adipose-tissue triacylglycerols.

The ranges of isotope compositions of fatty acids for individual acids differed (Gilmour et al. 1995). For palmitic acid (16:0), the $\delta^{13} \mathrm{C}$ value was $3.9 \%$ compared with $6.9 \%$ for palmitoleic acid $(16: 1 n-7), 9.2 \%$ for stearic acid $(18: 0), 6 \%$ for oleic acid $(18: 1 n-9)$, and $3.7 \%$ for $20: 1$. The mean $\delta^{13} \mathrm{C}$ values for $\mathrm{C}_{18: 1}$ and $\mathrm{C}_{20: 1}$ were heavier than expected, about -26 to $-27 \%$, which may indicate that the foxes were obtaining these nutrients from high up in the marine food chain, probably by eating the eggs or chicks of fish-eating sea-birds such as auks and puffins.

The isotope compositions of two $\mathrm{C}_{18}$ acids and the two $\mathrm{C}_{16}$ acids correlate, as do those of the saturated acids, 16:0 and 18:0 (Fig. 2), indicating that the foxes were obtaining these lipids from the same sources. The compositions of the different fatty acids are determined by the marine and terrestrial origins of the diet, unaltered by transformations introduced by the foxes' metabolism. The data in Fig. 2 indicate that, as might be expected for a predator and scavenger of mainly vertebrate prey, there is little interconversion between these common fatty acids in fox tissues. The unsaturated acids, 16:1 and 18:1, correlate only weakly and there was no significant correlation between the isotope composition of $20: 1$ and that of any other acid. In estuarine mussels, saturated fatty acids are isotopically slightly heavier than the corresponding mono- and polyunsaturates (Murphy \& Abrajano, 1994), probably because of discrimination against the ${ }^{13} \mathrm{C}$ isotope in desaturation reactions. 

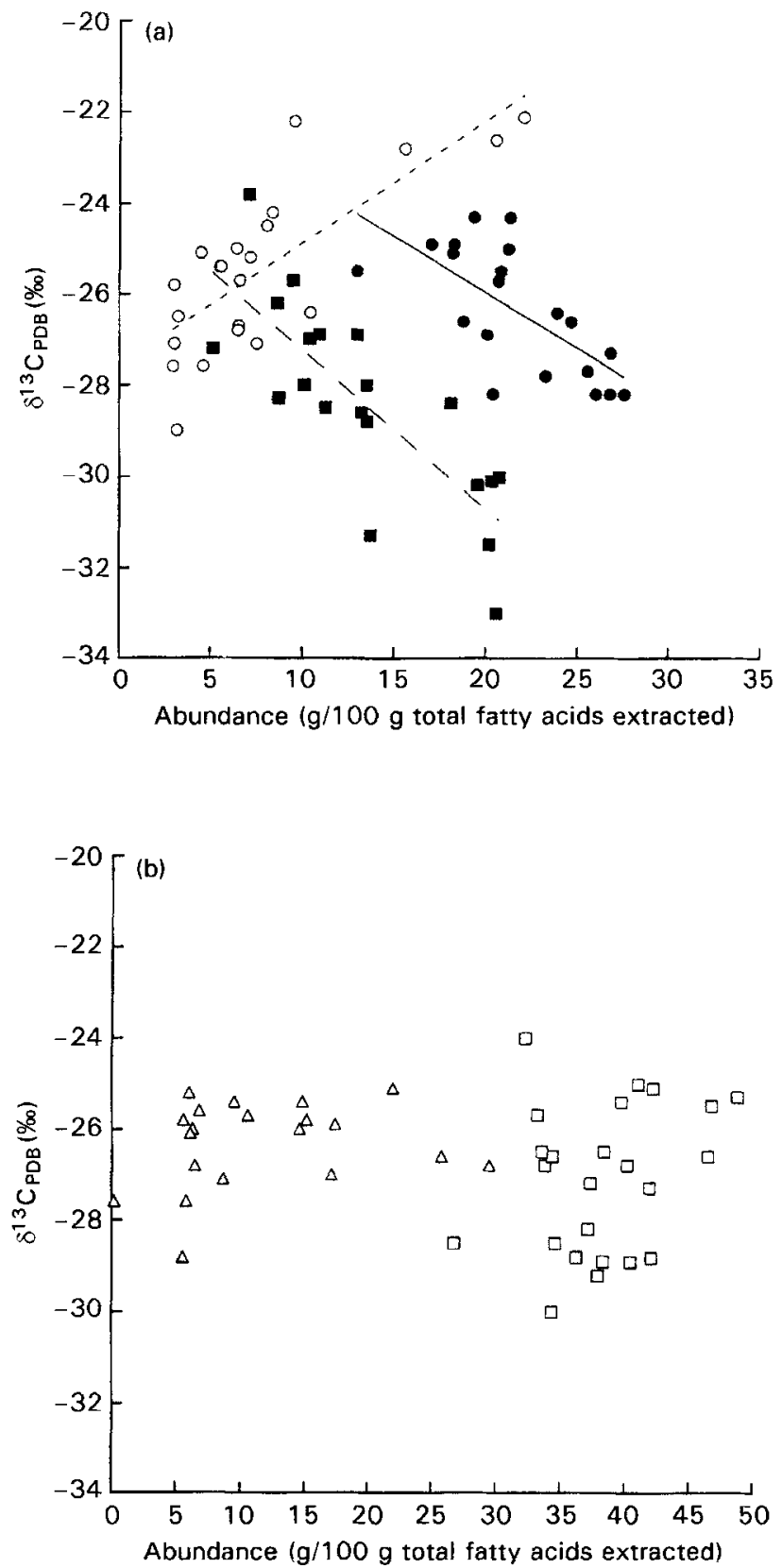

Fig. 1. The carbon isotopic composition, measured as the ratio $\delta^{13} \mathrm{C}$ relative to the Peedee belemnite standard $\left(\delta^{13} \mathrm{C}_{\mathrm{PDB}}\right)$ of various fatty acids $v$. their abundance relative to the total fatty acids extracted. (a) (•), Palmitic acid $\left(\mathrm{C}_{16: 0}\right) r-0.68$. $P<0.01 ;(\square)$, stearic acid $\left(\mathrm{C}_{18: 0}\right), r-0.79, P<0.01 ;(\mathrm{O})$, palmitoleic acid $\left(\mathrm{C}_{16: 1 n-7}\right), r 0.77, P<0.01$. (b) ( $\left.\square\right)$, Oleic acid $\left(C_{18: 1 n-9}\right) ;(\triangle)$, gondoic acid $\left(C_{20: 1 n-9}\right)$. Neither shows any significant correlation with abundance $(r 0.25, P>0.2)$. (Redrawn from Pond et al. 1995 and Gilmour et al. 1995.) 

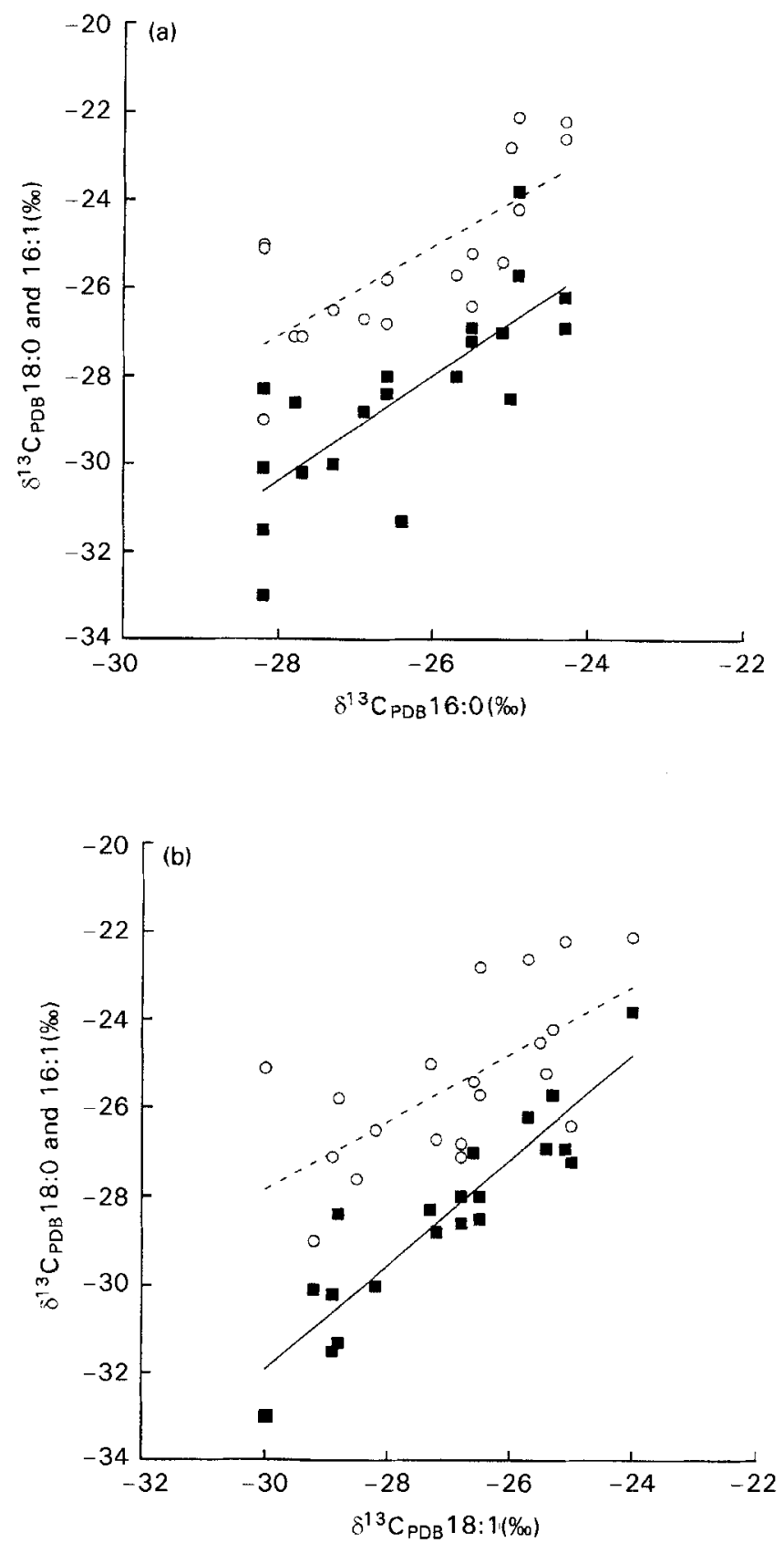

Fig. 2. Correlations between isotopic compositions of fatty acids from the same samples. The $\delta^{13} \mathrm{C}_{\mathrm{PDB}}$ values for stearic acid $(\square)$ and palmitoleic acid $(O)$ are compared with (a) $\delta^{13} \mathrm{C}$ values of palmitic acid $\left(\mathrm{C}_{16: 0}\right)$ : for stearic $r 0.77, P<0.01$ and for palmitoleic $r 0.74, P<0.01$. (b) $\delta^{13} \mathrm{C}$ values of the oleic acid $\left(\mathrm{C}_{18: 1 n-9}\right)$ : for stearic acid $r 0.92, P<0.01$ and for palmitoleic $r 0.66, P<0.01$. (Redrawn from Gilmour et al. 1995.) 
The relative abundance of ${ }^{13} \mathrm{C}$ in the unsaturated fatty acids shows that at least a large proportion arises from the marine food chain. Palmitoleic acid is very much more abundant in the marine food chain, and, in more complex ecosystems, in plants than in mammalian tissues (Hilditch \& Williams, 1964). In wild polar bears, about $21 \mathrm{~g} / 100 \mathrm{~g}$ triacylglycerolfatty acids in adipose tissue are palmitoleic acid (16:1n-7) and about $38 \mathrm{~g} / 100 \mathrm{~g}$ triacylglycerol-fatty acids are oleic acid (18:1n-9; Pond et al. 1992), but these lipids are much less plentiful in the adipose tissue of Svalbard reindeer (Pond et al. 1993), in which palmitoleic acid accounts for only $2.9 \mathrm{~g} / 100 \mathrm{~g}$ triacylglycerol-fatty acids, and oleic $32 \mathrm{~g} /$ $100 \mathrm{~g}$ triacylglycerol-fatty acids. All other unsaturated fatty acids together amount to less than $2 \mathrm{~g} / 100 \mathrm{~g}$ triacylglycerol-fatty acids.

The isotope data support the conclusion derived from the chemical-composition data that foxes must have obtained most of the monounsaturated fatty acids and almost all the polyunsaturated fatty acids found in their adipose tissue from the marine food chain. The isotope and chemical compositions of fatty acids in many of the foxes were closer to those of reindeer than to those of polar bears, suggesting that they were obtaining most of their food from the terrestrial food chain. However, none of the foxes studied contained storage lipids with as many saturated fatty acids as the ruminants, indicating that either all foxes include some sea-birds, fish or marine invertebrates in their diet or that some desaturation of fatty acids is taking place. In view of known metabolic capabilities of carnivores, the former interpretation is more likely.

Further deductions can be made from such data by combining them with biological information about the specimen's age and where and when it was caught (Pond et al. $1995 \mathrm{~b}$ ). These specimens came from four areas on the island of Spitsbergen: Gråhuken, on the north coast of Spitsbergen east of Woodfjorden between $79^{\circ} 40^{\prime}$ and $79^{\circ} 50^{\prime} \mathrm{N}$; Austfjordneset $\left(79^{\circ} 15^{\prime} \mathrm{N}\right)$, near the centre of the island at the end of a long, narrow fjord that opens on the north coast of the island; Tempelfjorden $\left(78^{\circ} 20^{\prime} \mathrm{N}\right)$, a branch of the eastern end of Isfjorden on the west side of Spitsbergen; in and around Adventdalen $\left(78^{\circ} 10^{\prime} \mathrm{N}\right)$, the most-heavily-populated area of the island, near the town of Longyearbyen on the southeast coast of Isfjorden. With their northern exposure, Austfjordneset and Gråhuken are more accessible to polar bears and other animals of the Arctic Ocean than Tempelfjorden and Austfjordneset, which face southwest.

In Gråhuken, all the foxes whose triacylglycerols included a high proportion of saturated fatty acids were either elderly (10 years) or less than 1 year old, and may have been newly arrived in the area or just passing through. All those with a greater proportion of unsaturates were of an age when they were probably resident territory holders and had been feeding in the area for some time. Where reindeer are absent, as at Austfjordneset, foxes may be feeding mainly in the marine food chain. They probably eat many sea-birds in summer, but all birds (except ptarmigan) migrate from Svalbard before the winter, thus, for half the year, the remains of polar bears' kills may be an important part of the foxes' diet. Radio-tracking data show that some juvenile foxes on Svalbard, especially males, travel very long distances (Frafjord \& Prestrud, 1992) and so may go to traps far from where they have been feeding in the weeks before capture.

The large and consistent differences in the fatty acid composition of storage lipids in specimens caught in the same area suggest that foxes in contiguous territories may have had quite different diets. This observation is consistent with the radio-tracking data showing that adult foxes are territorial and the territory-holders remain, and presumably feed, within the same range throughout the year (Prestrud, 1992b). The estimated average territory size is larger than that of the same species in Canada or Alaska, and many include, in differing proportions, both coastal and inland habitat, thereby providing a wider range of 
potential sources of food. The isotope data indicate that all the foxes ate small quantities of lipids of marine origin; they may be their only source of essential fatty acids and/or of the lipid-soluble vitamins associated with them.

The compositions of fatty acids from foxes caught around the human settlements in Adventdalen were not different from those of foxes caught in more remote areas, confirming the conclusion (Prestrud, 1992b) that human refuse makes only a minor contribution to the diet of this species. The large inter-individual differences in the composition of triacylglycerol-fatty acids could not be linked to any other aspect of body composition (Pond et al. 1995a), hence they probably had no serious effect on the animals' health. Despite the low species diversity of vertebrates on Svalbard, the foxes seem to roam over a large enough area to find adequate supplies of lipid nutrients. Like arctic foxes on Iceland (Hersteinsson \& Macdonald, 1996), this population seems to have a broad diet, and to adjust its feeding habits to the local availability of different foods.

\section{DISCUSSION}

Stable isotopes do not alter with time, therefore their use has the advantage that samples can be stored indefinitely, provided they are protected from chemical degradation. $\mathrm{C}$ is the easiest element to study because of its abundance in almost all biological materials, and it burns completely. During the last decade, advances in coupling stable-isotope mass spectrometers with chromatographic techniques have enabled precise determinations of stable-isotope compositions on individual, identified molecules, hence such measurements are becoming increasingly important in physiological and ecological research. But even with modern instruments, the isotope compositions of the major sources to be compared must be substantially different for the method to work reliably. Molecules that reach the consumers' tissues from similar sources via contrasting routes cannot be distinguished.

This method has to take account of possible fractionation of isotopes by chemical transformations such as elongation or desaturation. It could also be confounded by other metabolic processes that affect the congruence between dietary and storage lipids; for example, selective release by lipolysis (or retention) of certain fatty acids. Such phenomena have been demonstrated in rat adipocytes (Raclot \& Groscolas, 1993; Raclot et al. 1995; Connor et al. 1996) and during the breeding fast, the composition of king penguins' (Aptenodytes patagonicus) storage triacylglycerols appears to change. Presumably they selectively oxidize some fatty acids, while retaining others (Groscolas, 1990). Rouvinen et al. (1993) reported differences in the disposition and utilization of long-chain polyunsaturated fatty acids between quite closely related species of carnivores.

There may also be substantial differences in relative abundance of saturated and polyunsaturated fatty acids in triacylglycerols extracted from different areas of the same adipose depot (Mattacks \& Pond, 1997). As with all procedures that involve sampling, it is necessary to establish that the samples chosen for study yield reproducible results, and are representative of lipid metabolism in the body as a whole.

Examining $\mathrm{C}$ isotopes in fatty acids rather than those of collagen-amino acids has some important advantages for wildlife biology. Adipose-tissue triacylglycerols may be depleted and replenished very rapidly during fasting and refeeding, or continuous exercise such as migration, while bone collagen turns over only very slowly and at a constant rate (Ambrose \& DeNiro, 1986). Although our studies so far have been limited to cadaver material, the method could be adapted for use on free-living animals. Triacylglycerols are very concentrated in adipose tissue, thus only small quantities are needed for analysis. Taking biopsies of superficial adipose tissue is easy and minimally invasive, hence repeat sampling 
poses no significant risk to the subject, while sufficient bone can really only be obtained from carcasses, yielding only one post-mortem sample.

These advantages open the way to studying dietary changes associated with seasonal migration, breeding and hibernation, or following unscheduled periods of starvation and rehabilitation, such as recovery from injury or disease. Following changes in the uptake of nutrients by animals taken into long-term captivity and fed on an artificial diet would also be feasible with this method. Measurement of the natural abundance of $\mathrm{C}$ isotopes in lipids should be seen as complementary to that of structural proteins or inorganic skeletal material, offering scope for studying diet, habits and metabolic processes averaged over periods of months. We recommend compound-specific isotope analysis of lipids for such studies on species that are known to include suitable combinations of foods from contrasting sources in their diet.

The arctic fox data described in this paper were collected in collaboration with Pål Prestrud of The Norwegian Polar Research Institute and funded by a grant from The British Council to C.M.P. and Pål Prestrud. The compound-specific isotope analysis was carried out while I.G. held a Royal Society Research Fellowship.

\section{REFERENCES}

Abrajano, T. A., Murphy, D. E., Fang, J., Comet, P. \& Brooks, J. M. (1994). ${ }^{13} \mathrm{C} /{ }^{12} \mathrm{C}$ ratios in individual fatty acids of marine mytilids with and without bacterial symbionts. Organic Geochemistry 21, 611-617.

Ambrose, S. H. \& DeNiro, M. J. (1986). The isotopic ecology of East African mammals. Oecologia 69, 395406.

Angerbjörn, A., Hersteinsson, P., Lidén, K. \& Nelson, E. (1994). Dietary variation in arctic foxes (Alopex lagopus) - an analysis of stable carbon isotopes. Oecologia 99, 226-232.

Beylot, M. (1994). The use of stable isotopes and mass spectrometry in studying lipid metabolism. Proceedings of the Nutrition Society 53, 355-362.

Binnert, C., Laville, M., Pachiaudi, C., Rigalleau, V. \& Beylot, M. (1995). Use of gas chromatography isotope ratio mass spectrometry to study triglyceride metabolism in humans. Lipids 30, 869-873.

Brenner, R. R. (1989). Factors influencing fatty acid'chain elongation and desaturation. In The Role of Fats in Human Nutrition, pp. 46-79 [A. J. Vergroesen and M. Crawford, editors]. London: Academic Press.

Chisholm, B. S., Nelson, D. E. \& Schwartz, H. P. (1982). Stable carbon isotope ratios as a measure of marine versus terrestrial protein in ancient diets. Science 216, 1131-1132.

Colby, R. H., Mattacks, C. A. \& Pond, C. M. (1993). The gross anatomy, cellular structure and fatty acid composition of adipose tissue in captive polar bears (Ursus maritimus). Zoo Biology 12, 267-275.

Connor, W. E., Lin, D. S. \& Colvis, C. (1996). Differential mobilization of fatty acids from adipose tissue. Journal of Lipid Research 37, 290-298.

Cormie, A. B. \& Schwarcz, H. P. (1994). Stable isotopes of nitrogen and carbon of North American white tailed deer and implications for paleodietary and other food web studies. Palaeogeography Palaeoclimatology Palaeoecology 107, 227-241.

DeNiro, M. J. \& Epstein, S. (1977). Mechanism for carbon isotope fractionation associated with lipid synthesis. Science 197, 261-263.

DeNiro, M. J. \& Epstein, S. (1978). Influence of diet on the distribution of carbon isotopes in animals. Geochimica Cosmochimica Acta 42, 495-506.

Des Marais, D. J., Mitchell, J. M., Meinschein, W. G. \& Hayes J. M. (1980). The carbon isotopic biogeochemistry of the individual hydrocarbons in bat guano and the ecology of the insectivorous bats in the region of Carlsbad, New Mexico. Geochimica Cosmochimica Acta 44, 2075-2086.

Engel, M. H. \& Macko, S. A. (1984). Separation of amino acid enantiomers by high-performance liquid chromatography for stable nitrogen and carbon isotopic analysis. Analytical Chemistry 56, 2598-2600.

Fay, F. H. \& Stephenson, R. O. (1989). Annual, seasonal, and habitat-related variation in feeding habits of the arctic fox (Alopex lagopus) on St Lawrence Island, Bering Sea. Canadian Journal of Zoology 67, 1986-1994.

Frafjord, K. (1993). Food habits of arctic foxes (Alopex lagopus) on the western coast of Svalbard. Arctic 46, 49-54.

Frafjord, K. \& Prestrud, P. (1992), Home range and movements of arctic foxes (Alopex lagopus) in Svalbard. Polar Biology 12, 519-526.

Fry, B. \& Sherr, E. B. (1984). $\delta^{13} \mathrm{C}$ measurements as indicators of carbon flow in marine and freshwater ecosystems. Contributions to Marine Science 27, 13-47. 
Garrott, R. A., Eberhardt, L. E. \& Hanson, W. C. (1983). Summer food habits of juvenile arctic foxes in northern Alaska. Joumal of Wildlife Management 47, 540-545.

Gilmour, I., Johnston, M. A., Pillinger, C. T., Pond, C. M., Mattacks, C. A. \& Prestrud, P. (1995). The carbon isotopic composition of individual fatty acids as indicators of dietary history in arctic foxes on Svalbard. Philosophical Transactions of the Royal Society B 349, 135-142.

Gilmour, I. \& Pillinger, C. T. (1994). Isotopic compositions of individual polycyclic aromatic hydrocarbons from the Murchison meteorite. Monthly Notices of the Royal Astronomical Society 269, 235-240.

Gilmour, I., Swart, P. K. \& Pillinger, C. T. (1984). The carbon isotopic composition of individual petroleum lipids. Organic Geochemistry 6, 665-670.

Groscolas, R. (1990). Metabolic adaptations to fasting in emperor and king penguins. In Penguin Biology, pp. 269-296 [L. S. Davis and J. T. Darby, editors]. San Diego and New York: Academic Press.

Guo, Z. K., Luke, A. H., Lee, W. P. \& Schoeller, D. (1993). Compound-specific carbon-isotope ratio determination of enriched cholesterol. Analytical Chemistry 65, 1954-1959.

Gurr, M. I. \& Harwood, J. L. (1991). Lipid Biochemistry: An Introduction, 4th ed. London: Chapman \& Hall.

Harlow, J. J. \& Varnell, T. R. (1980). Winter changes in fatty acid composition of badger and coyote tissues. Comparative Biochemistry and Physiology 67A, 211-214.

Harrigan, P., Zieman, J. C. \& Macko, S. A. (1989). The base of nutritional support for the gray snapper (Lutjanus griseus): an evaluation based on combined stomach content and stable isotope analysis. Bulletin of Marine Science 44, 65-77.

Hayes, J. M., Freeman, K. H., Popp, B. N. \& Hoham, C. H. (1990). Compound-specific isotopic analyses - a novel tool for reconstruction of ancient biogeochemical processes. Organic Geochemistry 16, 1115-1128.

Hersteinsson, P. \& Macdonald, D. W. (1996). Diet of arctic foxes (Alopex lagopus) in Iceland. Journal of Zoology, London 240, 457-474.

Hilditch, T. P. \& Williams, P. N. (1964). Chemical Constitution of Natural Fats, 4th ed. New York: John Wiley.

Johnston, M. A, Yellowlees, D. \& Gilmour, I. (1995). Carbon isotopic analysis of the free fatty acids in a tridacnid algal symbiosis - interpretation and implications for the symbiotic association. Proceedings of the Royal Society of London B 260, 293-297.

McConnaughey, T. \& McRoy, C. P. (1979). Food-web structure and the fractionation of carbon isotopes in the Bering sea. Marine Biology 53, 257-262.

Mattacks, C. A. \& Pond, C. M. (1997). The effects of feeding suet-enriched chow on site-specific differences in the composition of triacylglycerol-fatty acids in adipose tissue and its interactions in vitro with lymphoid cells. British Journal of Nutrition 77, 621-643.

Matthews, D. E. \& Hayes, J. M. (1978). Isotope ratio monitoring gas chromatography mass spectrometry. Analytical Chemistry 50, 1465.

Metges, C. C., Petzke, K. J. \& Hennig, U. (1996). Gas chromatography combustion isotope ratio mass spectrometric comparison of $\mathrm{N}$-acetyl and $\mathrm{N}$-pivaloyl amino acid esters to measure ${ }^{15} \mathrm{~N}$ isotopic abundances in physiological samples - a pilot study on amino acid synthesis in the upper gastrointestinal tract of mini pigs. Journal of Mass Spectrometry 31, 367-376.

Moers, M. E. C., Jones, D. M., Eakin, P. A., Fallick, A. E., Griffiths, H. \& Larter, S. R. (1993). Carbohydrate diagenesis in hypersaline environments: application of GC-IRMS to the stable isotope analysis of derivatized saccharides from surficial and buried sediments. Organic Geochemistry 20, 927-934.

Murphy, D. E. \& Abrajano, T. A. (1994). Carbon isotope compositions of fatty acids in mussels from Newfoundland estuaries. Estuarine Coastal and Shelf Science 39, 261-272.

Nielsen, S. M. (1991). Fishing arctic foxes, Alopex lagopus, on a rocky island in west Greenland. Polar Research 9, 211-213.

O'Leary, M. H. (1981). Carbon isotope fractionation in plants. Phytochemistry 20, 553-567.

Ostrom, P. H. \& Fry, B. (1993). Sources and cycling of organic matter within modern and prehistoric food webs. In Organic Geochemistry, Principles and Applications, pp. 785-798 [M. H. Engel and S. A. Macko, editors]. New York: Plenum Press.

Ostrom, P. H., Macko, S. A., Engel, M. H., Silfer, J. A. \& Russell, D. (1990). Geochemical characterization of high molecular weight material isolated from late Cretaceous fossils. Organic Geochemistry 16, 1139-1144.

Pond, C. M., Mattacks, C. A., Colby, R. H. \& Ramsay, M. A. (1992). The anatomy, chemical composition and metabolism of adipose tissue in wild polar bears (Ursus maritimus). Canadian Journal of Zoology 70, 326-341.

Pond, C. M., Mattacks, C. A., Colby, R. H. \& Tyler, N. J. (1993). The anatomy, chemical composition and maximum glycolytic capacity of adipose tissue in wild Svalbard reindeer (Rangifer tarandus platyrhynchus) in winter. Journal of Zoology, London 229, 17-40.

Pond, C. M., Mattacks, C. A., Gilmour, I., Johnston, M. A., Pillinger, C. T. \& Prestrud, P. (1995b). Chemical and carbon isotopic composition of fatty acids in adipose tissue as indicators of dietary history in wild arctic foxes (Alopex lagopus) on Svalbard. Journal of Zoology, London 236, 611-623.

Pond, C. M., Mattacks, C. A. \& Prestrud, P. (1995a). Variability in the distribution and composition of adipose tissue in arctic foxes (Alopex lagopus) on Svalbard. Journal of Zoology, London 236, 593-610.

Pond, C. M., Mattacks, C. A. \& Ramsay, M. A. (1994). The anatomy and chemical composition of adipose tissue in wild wolverines (Gulo gulo) in northern Canada. Journal of Zoology, London 232, 603-616. 
Prestrud, P. (1992a). Food habits and observations of the hunting behaviour of arctic foxes, Alopex lagopus, in Svalbard. Canadian Field Naturalist 106, 225-236.

Prestrud, P. (1992b). Denning and home-range characteristics of breeding arctic foxes in Svalbard. Canadian Journal of Zoology 70, 1276-1283.

Prestrud, P. \& Nilssen, K. (1992). Fat deposition and seasonal variation in body composition of arctic foxes in Svalbard. Journal of Wildlife Management 56, 221-233.

Quinlan, S. E. \& Lehnhausen, W. A. (1982). Arctic fox, Alopex lagopus, predation on nesting common eiders, Somateria mollissma, at Icy Cape, Alaska. Canadian Field Naturalist 96, 462-466.

Raclot, T. \& Groscolas, R. (1993). Differential mobilization of white adipose tissue fatty acids according to chain length, unsaturation, and positional isomerism. Journal of Lipid Research 34, 1515-1526.

Raclot, T., Mioskowski, E., Bach, A. C. \& Groscolas, R. (1995). Selectivity of fatty acid mobilization: a general metabolic feature of adipose tissue. American Journal of Physiology 269, R1060-R1067.

Ramsay, M. A. \& Hobson, K. A. (1991). Polar bears make little use of terrestrial food webs: evidence from stable-carbon isotope analysis. Oecologia 86, 598-600.

Reidinger, R. F., Labows, J. N., Fellows, D. \& Mason, J. R. (1985). Fatty acid composition of adipose tissue as an indicator of diet: a preliminary assessment. Journal of Wildlife Management 49, 170-177.

Rönning, O. I. (1979). Svalbard Flora. Polar Handbook 1. Oslo: Norsk Polarinstitutt.

Rouvinen, K. \& Kiiskinen, T. (1989). Influence of dietary fat source on the body fat composition of mink (Mustela vison) and blue fox (Alopex lagopus). Acta Agriculturae Scandinavica 39, 279-288.

Rouvinen, K., Mäkelä, J., Kiiskinen, T. \& Nummela, S. (1993). Accumulation of dietary fish fatty acids in the body fat reserves of some carnivorous fur-bearing animals. Agricultural Science in Finland 1, 483490.

Schell, D. M. \& Ziemann, P. J. (1989). Natural carbon isotope tracers in arctic aquatic food webs. In Stable Isotopes in Ecological Research, pp. 230-251 [P. W. Rundel, J. R. Ehleringer and K. A. Nagy, editors]. Berlin: Springer Verlag.

Schoell, M. \& Hayes, J. M. (1994). Compound specific isotopic analysis in biogeochemistry and petroleum research - Introduction. Organic Geochemistry 21, R5.

Schoeninger, M. J. \& DeNiro, M. J. (1984). Nitrogen and carbon isotopic composition of bone collagen from marine and terrestrial mammals. Geochimica Cosmochimica Acta 48, 625-639.

Schoeninger, M. J., DeNiro, M. J. \& Tauber, H. (1983). Stable nitrogen isotope ratios of bone collagen reflect marine and terrestrial components of prehistoric human diet. Science 220, 1381-1383.

Silfer, J. A., Engel, M. H., Macko, S. A. \& Jumeau, E. J. (1991). Stable carbon isotope analysis of amino acid enantiomers by conventional isotope ratio mass spectrometry and combined gas chromatography/isotope ratio mass spectrometry. Analytical Chemistry 63, 370-374.

Smith, B. N. \& Epstein, S. (1971). Two categories of ${ }^{13} \mathrm{C} /{ }^{12} \mathrm{C}$ ratios for higher plants. Plant Physiology 47, 380384.

Smits, C. M. M., Slough, B. G. \& Yasui, C. A. (1989). Summer food habits of sympatric arctic foxes, Alopex lagopus, and red foxes, Vulpes vulpes, in the northern Yukon Territory. Canadian Field Naturalist 103, 363367.

Stickney, A. (1991). Seasonal patterns of prey availability and the foraging behavior of arctic foxes (Alopex lagopus) in a waterfowl nesting area. Canadian Journal of Zoology 69, 2853-2859.

Stirling, I. (1988). Polar Bears. Ann Arbor, MI: University of Michigan Press.

Thompson, D. R., Furness, R. W. \& Lewis, S. A. (1995). Diets and long-term changes in $\delta^{15} \mathrm{~N}$ and $\delta^{13} \mathrm{C}$ values in northern fulmars Fulmarus glacialis from two Northeast Atlantic colonies. Marine Ecology Progress Series 125, 3-11.

Tieszen, L. L. \& Boutton, T. W. (1988). Stable carbon isotopes in terrestrial ecosystem research. In Stable Isotopes in Ecological Research, pp. 167-195 [P. W. Rundel, J. R. Ehleringer and K. A. Nagy, editors]. Berlin: Springer-Verlag.

Tieszen, L. L., Boutton, T. W., Tesdahl, K. G. \& Slade, N. A. (1983). Fractionation and turnover of stable carbon isotopes in animal tissues: Implications for $\delta^{13} \mathrm{C}$ analysis of diet. Oecologia 57, 32-37.

Tjønneland, A., Overvad, K., Thorling, E. \& Ewertz, M. (1993). Adipose tissue fatty acids as biomarkers of dietary exposure in Danish men and women. American Journal of Clinical Nutrition 57, 629-633.

Tuross, N., Fogel, M. L. \& Hare, P. E. (1988). Variability in the preservation of the isotopic composition of collagen from fossil bone. Geochimica Cosmochimica Acta 52, 929-935.

Tykot, R. H., Vandermerwe, N. J. \& Hammond, N. (1996). Stable isotope analysis of bone collagen, bone apatite, and tooth enamel in the reconstruction of human diet - a case study from Cuello, Belize. American Chemical Society Symposium Series 625, 355-365.

Unander, S., Mortensen, A. \& Elvebakk, A. (1985). Seasonal changes in crop content of the Svalbard Ptarmigan Lagopus mutus hyperboreus. Polar Research 3, 239-245.

Wada, E., Mizutani, H. \& Minagawa, M. (1991). The use of stable isotopes for food web analysis. Critical Reviews in Food Science and Nutrition 30, 361-371. 